\title{
ВЛИЯНИЕ СОВРЕМЕННОЙ СОЦИОКУЛЬТУРНЫЙ СРЕДЫ НА ЖЕНСКУЮ ПРЕСТУПНОСТЬ
}

\section{INFLUENCE OF THE MODERN SOCIO-CULTURAL ENVIRONMENT ON WOMEN'S CRIME}

\section{O. Sulimova}

Summary: The relevance of the topic of women's crime is growing from year to year, as the criminalization of women's behavior leads to the degradation of modern society, because at all times women acted as the guardian of the home, kept and transmitted basic social values. This article attempts to study the influence of the socio-cultural sphere on the level of female crime. The main determinants of female crime and its consequences are revealed.

Keywords: women's crime, socio-cultural environment, family and domestic violence, illegal act, crime, causes, consequences.
Ж енская преступность, в качестве самостоятельной, начала выделяться только в последнее десятилетие. Данный факт связан с тем, что на сегодняшний день накопилась и существенно обогатилась информационная база по женской преступности, а так же с тем, что с каждым годом масштабы проводимых исследований расширяются.

Значительное число исследований посвятил изучению женской преступности В.А. Серебряков, который считает, что различия между женской и мужской преступностью необходимо искать в комплексе сложных социально-культурных факторов, которые, собственно, и определяют особенности поведения мужчин и женщин. При этом, отмечает В.А. Серебряков, следует учитывать особенности в различиях занятости преступников женского пола в быту, на производстве и др. [8]

Определенный интерес представляют и работы, объясняющие женскую преступность с позиций социологии, психологии и психиатрии. К числу таких исследователей можно отнести работы В.А Внукова, который объясняет женскую преступность простыми силовыми реакциями на агрессивную и неблагоприятную социальную среду. Кроме того, вопросы женской преступности исследовали в своих работах такие ученые как Маньковский Б.С., Звербуля А.К., Середа Е.В. и другие.

Женской преступности присущи свои особенности, связанные с тем, что женщины в силу своих природных особенностей имеют целый ряд отличительных черт с

\author{
Сулимова Ольга Николаевна \\ Аспирант, Майкопский Государственный \\ Технологический Университет \\ yulia_z09@mai.ru
}

Аннотация: Актуальность темы женкой преступность растет из года в год, так как криминализация женского поведения ведет к деградации современного общества, ведь во все временя, женщины, выступала в роли хранительницы домашнего очага, хранила и передавала базовые социальные ценности. В рамках данной статьи предпринята попытка изучения влияния социокультурной сферы на уровень женской преступности. Выявлены основные детерминанты женской преступности и ее последствия.

Ключевые слова: женская преступность, социокультурная среда, семейное и бытовое насилие, противоправное деяние, преступление, причины, последствия.

точки зрения психологии, которые, в свою очередь, связаны с физиологическими особенностями.

Подобные особенности не могут не отразиться на поступках женщин, на характере проявляемых ими реакций на те, или иные ситуации, а так же на те условия, в которых они оказались. Реакция женщины на какиелибо внешние раздражители именно так, а не как-то подругому именно потому, что она женщина.

Только углубленное изучение влияния социального окружения, а так же биологических и психологических особенностей женского организма позволит более детально исследовать явление женской преступности и позволит разработать необходимые меры по ее профилактике и предупреждению.

По данным приведенным на портале правовой статистики Генеральной прокуратуры РФ в 2019 году на территории России было совершено 141857 преступлений лицами женского пола преступления [7].

Анализ данных с 2006 по 2019 годы, предоставленных главным информационно-аналитическим центром МВД РФ можно сделать вывод о том, что доля убийств совершенных женщинами увеличилась с 19,9\% до 24,7\%.

Таким образом, доля особо тяжких преступлений в структуре женской преступности возросла на 4,8\%.

В то же время в этот же период времени несколько 
сократилось число преступлений, совершенных женщинами, связанных с нанесением тяжкого вреда здоровью - с 12, 7\% до 8,2\%, а так же сокращение грабежей и разбойных нападений - с 11, 3\% до 5\% [2].

Кроме того, на сегодняшний день отмечается существенный прирост доли несовершеннолетних преступниц. Так за рассматриваемый период времени с 2006 по 2019 годы доля несовершеннолетних преступниц выросла с 6,5\% до 8,1\%. В соответствии с данными приводимыми ГИАЦ МВД РФ, число девочек-подростков, совершивших преступления различной степени тяжести составило в 2019 году 113 человек [2].

С течением истории условия и образ жизни женщин меняется, меняется социокультурная среда, и соответственно изменяются и способы, и характер совершаемых женщинами преступлений.

В последние годы женской преступности стали присущи следующие основные тенденции:

- отмечается рост числа самосудов (большая часть преступлений приходится на домашнее насилие и расправу с домашними тиранами);

- отмечается числа женщин - преступниц возрастной категории от 18 до 29 лет;

- увеличение доли преступлений связанных с алкоголизмом и наркоманией;

- рост уровня жестокости, что в последние годы практически сблизило преступления совершаемые женщинами, с аналогичными преступлениями совершаемыми мужчинами по характеру насилия.

Как отмечается в исследовании, произведенном С.А. Поповой, на сегодняшний день отмечается склонность женщин к вступлению в организованные преступные группировки. При этом женщины стали чаще возглавлять такие ОПГ и совершать преступления с использованием огнестрельного и холодного оружия [6].

В соответствии с данными приведенными Т.М. Явчуновской и И.Б. Степановой основная возрастная категория среди женщин совершивших преступления - это женщины до 30 лет [9].

Женщины - преступницы в возрасте 40 лет и старше в своем большинстве одиноки. Уровень образования в основном средний или среднеОспециальный. При этом у многих из женщин-преступниц можно отметить низкий уровень трудовой занятости: порядка 40\% женщин не имеют постоянной работы. Говоря о семейном статусе женщин-преступниц необходимо отметить, что чуть больше 50\% состоят в браке, $67,7 \%$ - имеют двух и более детей.

В то же время многие исследователи указывают на тот факт, что «женщины - преступницы имеют гораздо меньше, чем мужчины асоциальных установок, они не имеют устойчивых преступных убеждений. При этом уровень социально-психологической адаптации у женщин-преступниц не настолько нарушен как у мужчин [1].

В связи с чем, можно констатировать, что рост женской преступности определяет криминальную картину современного общества.

К.А. Демина [3] приводит следующие данные по статистике женской преступности, которые свидетельствуют о том, что «на момент совершения преступного деяния нигде не работали порядка 61,7\% женщин, имели работу только $32,6 \%$, ходили на учебу - 5,7\%. По роду занятий женщин-преступниц можно структурировать следующим образом:

- трудоспособные женщины, которые не имели определенного занятия - от 55 до 68\%;

- женщины, работающие по найму - от 16 до 18\%» [4].

Таким образом, можно сделать вывод о том, что основная доля женщин-преступниц - это лица, не имеющие источника постоянного дохода.

Приведенные статистические данные свидетельствуют о том, что на преступления чаще идут женщины, не имеющие образования и постоянного места работы, а соответственно и стабильного источника дохода.

Приведенные факты позволяют сделать вывод о том, что основными факторами, толкающими женщин на совершение тех или иных преступлений, выступают социокультурные и социально-экономические условия. Именно этим можно объяснить факт того, что среди преступлений совершенных представительницами женского пола особо место отводится преступлениям, направленным против собственности.

Особая роль в обусловленности женской преступности находит свое выражение в обесценивании нравственных и культурных ценностей. Данный факт вызывает высокое беспокойство, как со стороны психологов, так и социологов, которые указывают на наличие следующих проблем:

- женщинам в России, равно как и во всем мире, присуще чувство отсутствия смысла жизни, неумение найти в ней свое место и цель;

- усиление выраженности синдрома «тревожного ожидания»;

- отсутствие уверенности в завтрашнем дне;

- частичная деморализация межличностных отношений в семье и в обществе;

- активный рост уровня конфликтности.

Сложившиеся в современном обществе обстоятель- 
ства оказывают подавляющее влияние на личность женщины, в свою очередь продуцируя совершение противоправных деяний.

Сопутствующей причиной криминализации женщин является нарушения правосознания, которые находят свое проявление в таких сферах как: развитие правового нигилизма, правовая безграмотность, недоверие правоохранительным властям, отсутствие веры в правосудие и равенства все слоем населения перед законом, страх за свою собственную безопасность и безопасность своих близких и др..

Особый взгляд в среде правозащитников имеется и на проблемы семейно-бытового характера, которые выступают в роли основного стимула женской преступности, и находят свое отражение в противоречии интересов членов семьи и самой женщины. Семейные проблемы стимулируют развитие семейного насилия, утрату взаимопонимания, столкновение интересов между представителями разных поколений проживающих в одной семье (проблемы отцов и детей) и т.д.

Раннее вступление в брак, ранние беременности, увеличение числа разводов, обесценивание ценностей института семьи и брака во многом являются причинами того, что изначальная роль женщины в качестве хранительницы очага уничижается, что ведет к росту совершения преступлений.

Обобщение вышеназванных причин женской преступности позволяет нам согласиться с мнением В.В. Лунеева [5], согласно которому основной причиной толкающей женщин на совершение противоправных деяний выступает отсутствие по отношению к ним социальной справедливости, а так же довольно низкий уровень раз- вития культуры в обществе, отсутствие уважения со стороны семьи, работы, мужчин.

Именно данный факт обуславливает наличие качественно отличных особенностей у женской преступности:

- среди женщин-преступниц ранее преобладали представительницы старшей возрастной категории, однако в последние годы наблюдается активное омоложение женской преступности;

- женщины обладают более высоким уровнем образования, чем преступники-мужчины;

- преступления, совершаемые женщинами, зачастую связаны с местом ее работы или с семейным насилием.

В связи с чем считаем необходимым сделать следующие обобщения:

Женская преступность активно растет: ежегодно увеличивается число осужденных к отбыванию наказания лиц женского пола.

Основные предпосылки подобного роста женской преступности необходимо искать в социально-экономической и социокультурной сферах, изобилующих проблемами, оказывающими прямое воздействие на преступное поведение женщин. Особенно тех, которые оказались в сложных жизненных обстоятельствах и не смогли найти поддержку от государства или общественности.

Для существенного снижения уровня женской преступности требуется на законодательном уровне проработать механизмы преступного сдерживания, а так же усилить уровень контроля за процессом в местах лишения свободы.

ЛИТЕРАТУРА

1. Гутиева И.Г. Проблемы противодействия экстремизму в молодежной среде // Пробелы в российском законодательстве. 2014. № 3. С. 258-261. Поступила в редакцию 06.11.2015

2. Главный информационно-аналитический центр МВД России https://xn--b1aew.xn--p1ai/mvd/structure1/Centri/Glavnij_informacionno_analiticheskij_cen

3. Демина К.А. Личность преступницы в аспекте особенностей ее социально-ролевой характеристики // Вестн. Томского государственного университета. 2016. № 331. C. 113-115.

4. Демина К.А. Некоторые социально-экономические детерминанты женской преступности (криминологический анализ на материалах федерального и регионального уровней) // Вестн. Томского государственного университета. 2015. № 337. С. 107-110.

5. Лунеев В.В. Криминологическая характеристика женской преступности // Труды института государства и права российской академии наук. Актуальные проблемы уголовного права и уголовного процесса. - М.: Ин-т гос. и права РАН, 2009, № 6. - С. 3-24

6. Попова С.А. Современная женская преступность: виды, причины, предупреждение // Следователь. Федеральное издание. - М., 2004, № 1. - С. $43-46$

7. Портал правовой статистики Генеральной прокуратуры РФ // http://crimestat.ru/

8. Серебрякова, В.А. Корыстные преступления, совершаемые женщинами [Текст] / В.А. Серебрякова - М., 1990.- 160с.

9. Явчуновская Т.М.. Степанова И.Б. Тенденции современной преступности женщин // Государство и право, 2000, № 12. С. 28.

(с Сулимова Ольга Николаевна (yulia_z09@mai.ru).

Журнал «Современная наука: актуальные проблемы теории и практики» 